\title{
Dopamine-Dependent Synaptic Plasticity in the Striatal Cholinergic Interneurons
}

\author{
Takeo Suzuki, ${ }^{1,2}$ Masami Miura, ${ }^{1}$ Kin-ya Nishimura, ${ }^{1,2}$ and Toshihiko Aosaki ${ }^{1}$ \\ ${ }^{1}$ Department of the Autonomic Nervous System, Tokyo Metropolitan Institute of Gerontology, Itabashi-ku, Tokyo 173- \\ 0015, Japan, and 2Department of Anesthesiology, School of Medicine, Juntendo University, Bunkyo-ku, \\ Tokyo 113-8421, Japan
}

The striatum, the input stage of the basal ganglia, is a critical brain structure for the learning of stimulus-response habits as well as motor, perceptual, and cognitive skills. Roles of dopamine (DA) and acetylcholine (ACh) in this form of implicit memory have long been considered essential, but the underlying cellular mechanism is still unclear. By means of patch-clamp recordings from corticostriatal slices of the mouse, we studied whether the identified striatal cholinergic interneurons undergo long-term synaptic changes after tetanic stimulation of corticoand thalamostriatal fibers. Electrical stimulation of the fibers revealed a depolarizing and hyperpolarizing postsynaptic potential in the striatal cholinergic interneurons. The early depolarizing phase was considered to be a cortico/thalamostriatal glutamatergic EPSP, and the hyperpolarizing component was considered to be an intrastriatally evoked GABAergic IPSP. Tetanic stimulation of cortico/thalamostriatal fibers was found

Striatal cholinergic activity plays a major role in the acquisition and early maintenance stages of instrumental learning (Salmon and Butters, 1995; White, 1997), whereas striatal dopaminergic activity influences memory consolidation in the striatum (PradoAlcalá, 1985). Unlike in other brain systems, acetylcholine (ACh) in the striatum is supplied exclusively from cholinergic interneurons, which account for $<2 \%$ of the entire striatal neuronal population but have widespread intranuclear arborization. Previous studies suggest that these giant aspiny neurons correspond to the tonically active neurons (TANs) of the monkey striatum. First, TANs fire tonically in vivo with wide action potentials, just as cholinergic interneurons do in vivo as well as in vitro (Wilson et al., 1990; Bennett and Wilson, 1999). Second, TANs are considered to be large intrinsic neurons, because they are detectable a long distance (up to $500 \mu \mathrm{m}$ ) along an extracellular electrode and are unresponsive to pallidal stimulation (Kimura et al., 1990). Finally, TANs are as sparsely distributed and preferentially located in the matrix, especially in the border regions between the matrix and striosomal compartments of the striatum, as are the immunostained cholinergic interneurons (Aosaki et al., 1995).

Received Jan. 3, 2001; revised June 7, 2001; accepted June 14, 2001.

This work was supported in part by Grants-in-Aid for Scientific Research from the Ministry of Education, Science and Culture of Japan, and by the Special Coordination Funds for Promoting Science and Technology Agency of Japan. We thank Dr. Shin Ryong-Moon for comments on this manuscript and Emi Iwatani for help with data analysis and language assistance.

T.S. and M.M. contributed equally to this work.

Correspondence should be addressed to Dr. Toshihiko Aosaki, Department of the Autonomic Nervous System, Tokyo Metropolitan Institute of Gerontology, 35-2, Sakae, Itabashi-ku, Tokyo 173-0015, Japan. E-mail: aosaki@tmig.or.jp.

Copyright (C) 2001 Society for Neuroscience $\quad 0270-6474 / 01 / 216492-10 \$ 15.00 / 0$ to induce simultaneously occurring long-term potentiation (LTP) of the EPSPs as well as the disynaptically mediated IPSPs. The induction of LTP of EPSP required a rise in intracellular $\mathrm{Ca}^{2+}$ concentration and dopamine $D_{5}$, but not $D_{2}$ receptor activation. $\mathrm{Ca}^{2+}$-permeable AMPA receptors might also play a part in the LTP induction. Blockade of NMDA receptors, metabotropic glutamate receptors, or serotonin receptors had no significant effects. The long-term enhancement of the disynaptic IPSPs was caused by a long-term increase in the occurrence rate but not the amplitude of disynaptically mediated IPSP in the striatal cholinergic interneurons. This dual mechanism of synaptic plasticity may be responsible for the long-term modulation of the cortico/thalamostriatal synaptic transmission.

Key words: LTP; dopamine; acetylcholine; striatum; cholinergic; synaptic plasticity

TANs appear not to fire in relation to movement as the phasically active neurons (or medium spiny neurons) do, but they respond to sensory stimuli that have been associated with reward during sensorimotor learning (Aosaki et al., 1994b). This modulation in activity is dependent on dopaminergic input from the substantia nigra that also develops conditioned responses during associative learning (Schultz et al., 1993; Aosaki et al., 1994a). The conditioned stimulus leads to a transient suppression in the ongoing tonic activity of TANs, which is often preceded by spike firing (Kimura et al., 1984). However, it is not known whether this conditioned pause response results from an alteration of synaptic efficacy of their own or from other types of neurons in the striatum.

A recent in vitro study proposed the idea that afterhyperpolarization (AHP) after a spike triggered by synaptic inputs in these cells may be the underlying cellular mechanism of the TAN pause response (Bennett and Wilson, 1998, 1999). However, activitydependent changes in synaptic efficacy in theses neurons might also play a key role in the TAN pause response, which remains an open question. Moreover, there is evidence that the inactivation of the centre-médian/parafascicular nucleus (CM-Pf) of the thalamus, which send glutamatergic inputs to the striatal cholinergic interneurons, spared the initial excitation but suppressed significantly the following pause and rebound facilitation of the TAN response in behaving monkeys (Lapper and Bolam, 1992; Matsumoto et al., 2001). This implies that the conditioned TAN response may be composed of at least two distinct mechanisms.

This study was therefore aimed at elucidating directly whether these cholinergic neurons develop long-term plastic changes after 
tetanic stimulation of the cortico- and thalamostriatal pathways in slice preparations of the mouse striatum. Our unexpected finding was that tetanic stimulation simultaneously induced LTP of EPSPs and LTP of the disynaptically mediated IPSPs in the striatal cholinergic interneurons (Suzuki et al., 2000).

\section{MATERIALS AND METHODS}

Slice preparation. Sagittal corticostriatal slices $(200-250 \mu \mathrm{m})$ were obtained from male postnatal day (P)14-P21 C57BL/6J mice. Slices were transferred to a holding chamber, incubated for $1 \mathrm{hr}$ at $30^{\circ} \mathrm{C}$, and then maintained at room temperature until recording. The bathing solution contained (in mM): $124 \mathrm{NaCl}, 3 \mathrm{KCl}, 2.4 \mathrm{CaCl}_{2}, 1.2 \mathrm{MgCl}_{2}, 26 \mathrm{NaHCO}_{3}$, $1 \mathrm{NaH}_{2} \mathrm{PO}_{4}$, and 10 glucose, saturated with $95 \% \mathrm{O}_{2} / 5 \% \mathrm{CO}_{2}, \mathrm{pH} 7.4$.

Visualized recording. Whole-cell patch-clamp recordings were made with an Axoclamp 2B amplifier (Axon Instruments) or EPC 9/2 amplifier (HEKA Elektronik) in either current-clamp or voltage-clamp mode, with infrared differential contrast (IR-DIC) visualization using an Olympus BX50WI and a charge-coupled device camera (Hamamatsu). For current-clamp recordings, patch pipettes (2-4 M $\Omega$ ) were filled with a solution containing (in $\mathrm{mM}$ ): $129 \mathrm{~K}$-gluconate, $11 \mathrm{KCl}, 2 \mathrm{MgCl}_{2}, 10$ HEPES, $4 \mathrm{Na}_{2}$-ATP, $0.3 \mathrm{GTP}$, and $0.5 \%$ biocytin (made to $\mathrm{pH} 7.3$ with $\mathrm{KOH}$; osmolarity, $280 \mathrm{mOsm}) . \mathrm{E}_{\mathrm{Cl}}$ was estimated as $-59 \mathrm{mV}$ at $35^{\circ} \mathrm{C}$ in our recording configuration.

Cortico- and thalamostriatal fibers in the sagittal slices were stimulated every $20 \mathrm{sec}$ in the corpus callosum dorsal to the striatum using a bipolar tungsten electrode (1.0 M $\Omega$; Micro Probe) and 50-500 $\mu$ sec constant current pulses at intensity sufficient to evoke a $50 \%$ maximal response $(100-800 \mu \mathrm{A})$. An electrical tetanus was administered for $1 \mathrm{sec}$ at $100 \mathrm{~Hz}$ using the same stimulus intensity but 50-100 $\mu$ sec longer current pulses to ensure spike firing during tetanus. If series resistance was changed by $>20 \%$, the experiment was discarded. Signals were filtered at $5 \mathrm{kHz}$ and digitized at $20 \mathrm{kHz}$ (ITC-16, Instrutech) with Pulse/PulseFit (HEKA) running on a Macintosh computer. Data were analyzed with Igor Pro (WaveMetrics). For analysis of long-term changes of EPSPs, their slopes were measured and plotted against time. Values obtained for the duration of $10 \mathrm{~min}$ before tetanus were taken as control values $(100 \%)$. The mean values were calculated from 15 data taken every $20 \mathrm{sec}(5 \mathrm{~min})$ and plotted at each end point. All values are expressed as means \pm SEM, unless indicated otherwise. Assessment of whether changes in EPSP slopes occurred after tetanus was made by paired $t$ test. Effects of drugs were estimated by statistical comparison between the control experiment with (-)-bicuculline methiodide (BMI) (see below) and the experiment with each drug. Statistical significance was assessed by the two-tailed Student's $t$ test or ANOVA, or both.

Gramicidin-perforated patch-clamp technique. The equilibrium potential for $\mathrm{Cl}^{-}$was obtained with gramicidin-perforated patch-clamp technique under a fluorescent microscope, taking advantage of the property of gramicidin that allows only monovalent cations to permeate the membrane with $\left[\mathrm{Cl}^{-}\right]_{\mathrm{i}}$ relatively intact (Abe et al., 1994). The pipette solution contained $150 \mathrm{~mm}$ K-gluconate, $10 \mathrm{~mm}$ HEPES, and $0.025 \%$ Lucifer yellow, pH 7.2. Gramicidin was dissolved in methanol $(10 \mathrm{mg} / \mathrm{ml})$ and diluted to the pipette solution at a final concentration of $5 \mu \mathrm{g} / \mathrm{ml}$. To obtain the equilibrium potential for $\mathrm{Cl}^{-}$, IPSCs were evoked by intrastriatal stimulation in the presence of 6-cyano-7-nitroquinoxaline-2,3dione (CNQX) and $\mathrm{D}(-)$-2-amino-5-phosphonovalerate (D-APV).

For voltage-clamp recordings, the intracellular solution contained (in $\mathrm{mM}): 124 \mathrm{Cs}-m e t h a n e s u l f o n a t e, 11 \mathrm{KCl}, 2 \mathrm{MgCl}_{2}, 10 \mathrm{HEPES}, 0.1$ EGTA, $4 \mathrm{Na}_{2}$-ATP, 0.3 GTP, and 5 QX-314 (made to pH 7.3 with $\mathrm{CsOH}$; osmolarity, $280 \mathrm{mOsm}$ ). Voltage errors attributable to the liquid junction potential were subtracted off-line.

Drug application. Drugs were obtained from Research Biochemicals (Natick, MA) or Sigma (St. Louis, MO) and were bath applied. BMI was used to block $\mathrm{GABA}_{\mathrm{A}}$ receptors at a concentration of $30 \mu \mathrm{M}$. CNQX (10 $\mu \mathrm{M})$ was applied to block AMPA/kainate receptors, and D-APV (50 $\mu \mathrm{M})$ was used for NMDA receptor blockade. ( $S$ )-methyl-3-carboxy-4hydroxyphenylglycine [(S)-MCPG; $1 \mathrm{mM}]$ was bath applied to block metabotropic glutamate $(\mathrm{mGlu})$ receptor. BAPTA was included in the patch pipette at $20 \mathrm{mM} . \mathrm{Ni}^{2+}(50 \mu \mathrm{M})$ and nimodipine $(10 \mu \mathrm{M})$ were applied to test the contribution of voltage-sensitive $\mathrm{Ca}^{2+}$ channels (VSCCs) before and during recording. Spermine $(0.1 \mathrm{~mm})$ was included in the pipette in some experiments. $N$-(4-hydroxyphenylpropanoyl)spermine (NHPP-spermine, $10 \mu \mathrm{M}$ ) and Joro spider toxin 3 (JSTX-3; 10 $\mu \mathrm{M})$ were bath applied to block $\mathrm{Ca}^{2+}$-permeable AMPA receptors.
SCH23390 $(10 \mu \mathrm{M})$ and $( \pm)$-sulpiride $(10 \mu \mathrm{M})$ were used to block dopamine (DA) $\mathrm{D}_{1}$-class and $\mathrm{D}_{2}$-class receptors, respectively.

Histochemical procedures. Slices containing biocytin-filled cells were fixed by immersion in $4 \%$ paraformaldehyde and $0.2 \%$ picric acid in 0.1 $\mathrm{M}$ phosphate buffer (PB) overnight at $4^{\circ} \mathrm{C}$, rinsed in $\mathrm{PB}$ for $30 \mathrm{~min}$, and incubated in $\mathrm{PB}$ containing $0.5 \% \mathrm{H}_{2} \mathrm{O}_{2}$ for $30 \mathrm{~min}$ to suppress endogenous peroxidase activity. They were then incubated in $20 \%$ sucrose at $4^{\circ} \mathrm{C}$ overnight and stored in a freezer until histochemistry was performed. The slices were then washed with Tris-buffered saline (TBS) containing $0.5 \%$ Triton X-100 and avidin-biotin-peroxidase complex (Vector Laboratories, Burlingame, CA) at a dilution of 1:100 for 4-6 hr at room temperature. After rinsing, the slices were reacted with $3,3^{\prime}$ diaminobenzidine tetrahydrochloride (DAB), stained using DAB reagent set (Kirkegaard \& Perry, Gaithersburg, MD), and mounted on slides.

\section{RESULTS}

\section{Physiological and morphological identification of the striatal cholinergic interneurons}

The striatal cholinergic interneurons were identified by their large somata and thick primary dendrites under IR-DIC optics. These cells showed repetitive regular spiking with relatively broad action potentials followed by a long-lasting AHP with depolarizing current injection and a sag in the membrane potential with hyperpolarization (Fig. 1 $A a, A b$ ) (Kawaguchi, 1992). Subsequent staining with biocytin revealed large somata with aspiny or sparsely spiny dendrites, indicative of large aspiny neurons (Fig. 1B).

\section{Two components in the postsynaptic potentials}

These interneurons are known to receive glutamatergic inputs from the neocortex (Thomas et al., 2000) and the CM-Pf of the thalamus (Lapper and Bolam, 1992). Electrical stimulation of the subcortical white matter in the sagittal brain slices, which contains both cortico- and thalamostriatal pathways, evoked monosynaptic EPSPs with a latency of $2.7 \pm 0.2 \mathrm{msec}$ (mean $\pm \mathrm{SEM} ; n=16$ ). These EPSPs were glutamatergic because application of both AMPA/kainate receptor antagonist CNQX $(10 \mu \mathrm{M})$ and NMDA receptor antagonist D-APV $(50 \mu \mathrm{M})$ blocked the EPSPs completely (data not shown). Yet curiously, an increase in stimulus strength gradually revealed a late-onset inhibitory component in 26 of 265 cells (Fig. 1C, arrow), which was abolished by $30 \mu \mathrm{M}$ $\mathrm{BMI}, \mathrm{a} \mathrm{GABA}_{\mathrm{A}}$ receptor antagonist. This component was shown to be a disynaptically mediated GABAergic IPSP because bath application of CNQX blocked both the EPSP and the inhibitory component (Fig. 1D). Thus, both monosynaptic EPSPs and disynaptic IPSPs were examined to elucidate the mechanism of synaptic plasticity in the cholinergic neurons.

\section{LTP of EPSP is $\mathrm{Ca}^{2+}$-dependent}

First we isolated the glutamatergic synaptic responses by continuous application of BMI $(30 \mu \mathrm{M})$ to test whether the cortico/ thalamostriatal synapse per se was responsible for long-term changes in the synaptic efficacy of the striatal cholinergic interneurons. It was reported that this neuronal type possessed a persistent sodium conductance that was activated between resting membrane potential and action potential threshold (Chao and Alzheimer, 1995). Because bath application of BMI tended to trigger the persistent depolarizing plateau potential that hampered the accurate measurement of the EPSP amplitude, its slope was observed instead. High-frequency stimulation (HFS) (100 $\mathrm{Hz}, 1 \mathrm{sec}$ ) reliably induced LTP that lasted for the duration of the recording (30-60 min after induction protocol) as exemplified in Figure $2 A a, b$. The difference of the mean EPSP slopes between before and after HFS was statistically significant throughout the experiment $(139.5 \pm 10.1 \%$ of baseline at $30 \mathrm{~min} ; p=0.0003$; 
A a

b
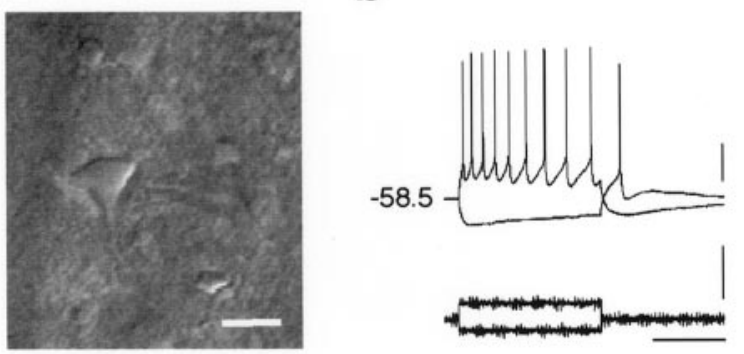

B a

b

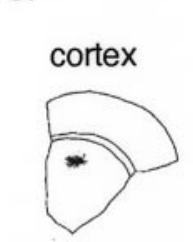

neostriatum

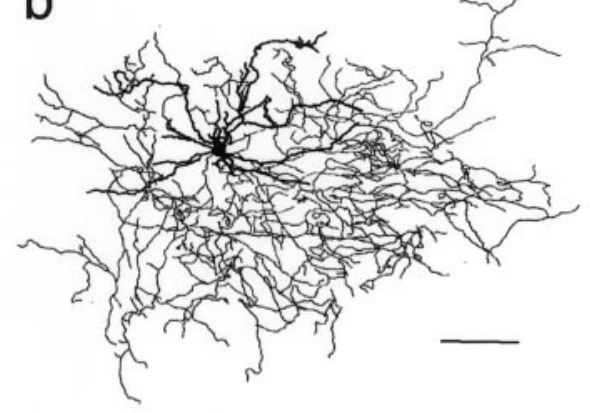

C
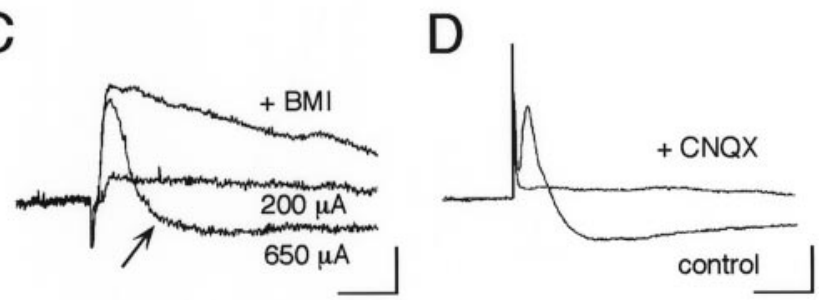

Figure 1. Cortico/thalamostriatal stimulation evokes EPSP as well as disynaptic IPSP in the striatal cholinergic interneurons. $A a$, IR-DIC video image of a cholinergic interneuron just before recording. This neuronal type is exceptionally large compared with other types of neurons. Average diameter: long, $19.5 \mu \mathrm{m}$; short, $13.5 \mu \mathrm{m}(n=32)$. Scale bar, $20 \mu \mathrm{m}$. $A b$, Current-clamp recordings from a cholinergic interneuron shown in $A a$ during injection of depolarizing and hyperpolarizing current pulses. Resting membrane potential was $-58.5 \mathrm{mV}$. Calibration: vertical bar, $20 \mathrm{mV}$ (top), $500 \mathrm{pA}$ (bottom); horizontal bar, $500 \mathrm{msec}$. Ba, Slice containing a large aspiny neuron, which was stained with biocytin during whole-cell recording and reconstructed in $B b . \mathrm{Bb}$, Dendrites (thick lines) and axons (thin lines) are superposed. Large aspiny cells had fewer spiny dendrites than medium spiny cells (data not shown). Note the wide distributions of both dendrites and axons. Scale bars: $a, 1 \mathrm{~mm} ; b, 100 \mu \mathrm{m}$. $C$, Postsynaptic potentials evoked by electrical stimulation (amplitude, 200 and $650 \mu \mathrm{A}$; duration, $400 \mu \mathrm{sec}$ ) of white matter. Note that a stimulus of larger amplitude $(650 \mu \mathrm{A})$ evoked a hyperpolarizing component after EPSP that was abolished by bath application of BMI $(30 \mu \mathrm{M} ;+B M I)$. D, Both components were completely abolished by CNQX $(10 \mu \mathrm{M} ;+C N Q X)$. Calibration $(C, D): 2 \mathrm{mV}, 20 \mathrm{msec}$.

$n=20$; paired $t$ test; statistical significance: $0-5$ min after HFS, $p<0.05$; after $5 \min , p<0.001 ; n=20$; paired $t$ test) (Fig. $2 B$, $\bigcirc)$. This LTP induction was blocked entirely by inclusion of the $\mathrm{Ca}^{2+}$ chelator, BAPTA $(20 \mathrm{~mm})$, in the whole-cell recording pipette $(95.9 \pm 8.5 \%$ at $30 \mathrm{~min} ; p=0.0068$, unpaired $t$ test; $p<$ 0.0001 , ANOVA; $n=10$ ) (Fig. $2 B, \mathbf{\Delta}$ ), showing that LTP induction requires a postsynaptic rise in intracellular $\mathrm{Ca}^{2+}$.

One possible source of this $\mathrm{Ca}^{2+}$ is the VSCCs. Striatal cholinergic interneurons possess several types of VSCCs, namely L-, Q-, N-, P-, and R-type (Yan and Surmeier, 1996). However, because antagonists of these channels may affect the presynaptic
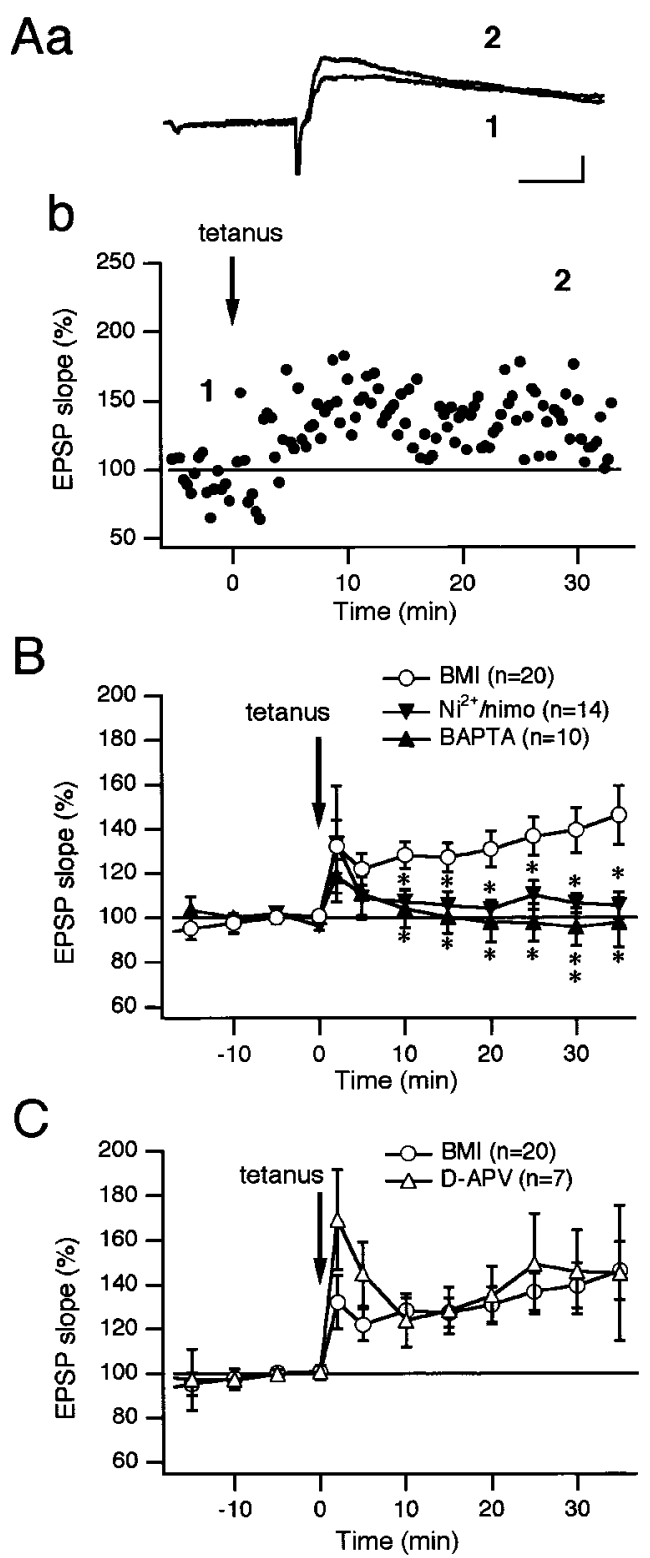

Figure 2. Long-term potentiation of cortico/thalamostriatal EPSP in cholinergic interneurons requires an increase in postsynaptic $\mathrm{Ca}^{2+}$. BMI (30 $\mu \mathrm{M})$ was added to the bath solution throughout the experiments. $A a$, EPSPs evoked before and after tetanic stimulation. Sweeps (4 min average) were taken at the times indicated on the graph in $A b$ (1 and 2). Calibration: $1 \mathrm{mV}$, 25 msec. $A b$, Percentage of each EPSP slope compared with the control values measured $10 \mathrm{~min}$ before the tetanus is plotted against time. Note that LTP occurred after the tetanus in the presence of BMI in the cholinergic interneuron. $B$, Average normalized EPSP slopes are plotted in the presence of BMI (O). Differences of the mean EPSP slopes between before and after HFS were statistically significant throughout the experiment $(0-5 \mathrm{~min}$ after HFS, $p<0.05$, paired $t$ test; after $5 \mathrm{~min}, p<0.001$, paired $t$ test; $n=$ $20)$. Loading cells with BAPTA $(20 \mathrm{~mm})$ blocked the induction of LTP $(\mathbf{\Delta})$. Pretreatment with $\mathrm{Ni}^{2+}(50 \mu \mathrm{M})$ and nimodipine $(10 \mu \mathrm{M})$ also failed to induce LTP $(\nabla)$. Thus, an increase in intracellular $\mathrm{Ca}^{2+}$ is required for LTP induction. When the experiment with BMI $(\bigcirc)$ was regarded as the control, the differences between the control and the experiment with $\mathrm{Ni}^{2+}$ and nimodipine became statistically significant throughout $10 \mathrm{~min}$ after the tetanus ( $p<0.05$, unpaired $t$ test; $p=0.0083$, ANOVA; $n=14)$. Differences between the control and the experiment with BAPTA were statistically significant all the time after $10 \mathrm{~min}(10-25$ min after HFS, $p<0.05$, unpaired $t$ test; 30 min after HFS, $p<0.01$, unpaired $t$ test; $p<0.0001$, ANOVA; $n=10)$. Statistical significance is indicated by asterisks on the graph: ${ }^{*} p<0.05,{ }^{* *} p<0.01$. $C$, Treatment with D-APV $(50 \mu \mathrm{M} ; \triangle ; n=7)$ $10 \mathrm{~min}$ before HFS did not block LTP induction ( $p=0.0586$, ANOVA). 
Aa
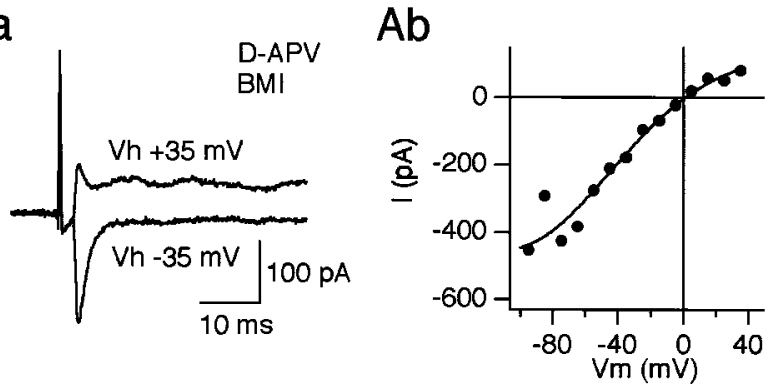

$\mathrm{Ba}$

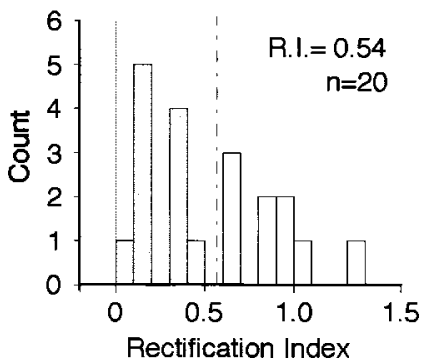

$\mathrm{Bb}$

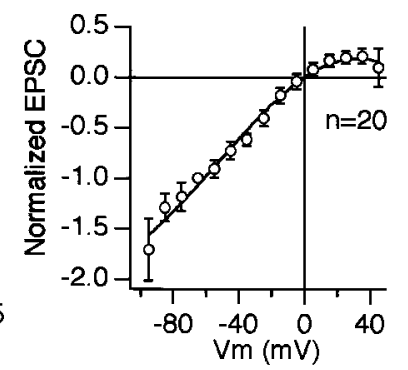

C NHPP spermine $10 \mu \mathrm{M}$

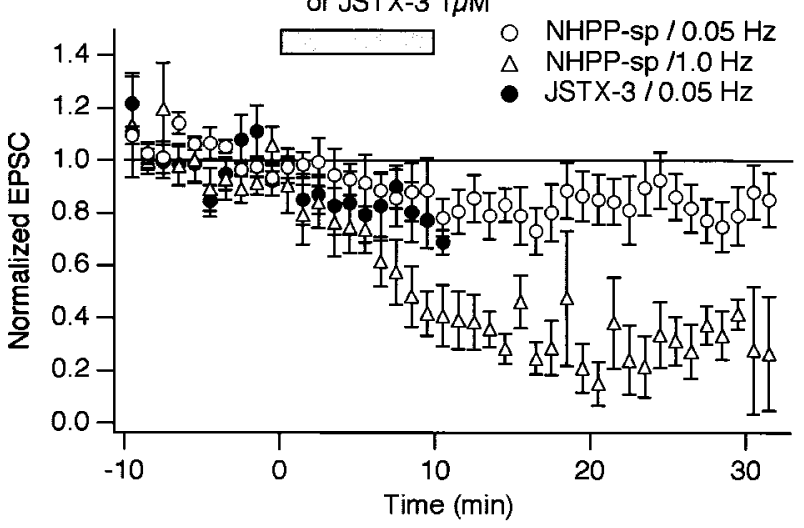

Figure 3. Striatal cholinergic interneurons possess $\mathrm{Ca}^{2+}$-permeable AMPA receptors. $A a$, Evoked synaptic currents recorded from a cholinergic interneuron at holding potentials of +35 and $-35 \mathrm{mV}$. Synaptic currents were recorded in the presence of D-APV $(50 \mu \mathrm{M})$ and BMI (30 $\mu \mathrm{M})$. Patch pipettes contained $\mathrm{CsCl}$. Note that the current amplitude of the AMPA receptor-mediated EPSC at $+35 \mathrm{mV}$ was smaller than that taken at $-35 \mathrm{mV}$. $A b$, Current-voltage relationship of AMPA EPSC taken from the same cell shown in $A a$. Ba, Rectification index (R.I.) is plotted for 20 cells. R.I. was defined as the conductance of the AMPA EPSC measured at $+40 \mathrm{mV}$ divided by the conductance at $-70 \mathrm{mV}$. Thus, the R.I. of $<0.57$ (broken line) was regarded as inward rectifying. Eleven of 20 cells were considered cells containing $\mathrm{Ca}^{2+}$-permeable AMPA receptors (gray bars). The averaged R.I. was 0.54. Bb, The currentvoltage relationship of normalized AMPA EPSCs obtained from 20 cholinergic interneurons shows inward rectification, indicating that this neuronal type as a whole possesses $\mathrm{Ca}^{2+}$-permeable AMPA receptors. The current amplitude taken at $-60 \mathrm{mV}$ was normalized to 1.0. The normalized values at each membrane potential were averaged across the cells and plotted against voltage to yield the averaged $I-V$ curve. $C$, Use-dependent block of $\mathrm{Ca}^{2+}$-permeable AMPA receptors by NHPPspermine and JSTX-3. Average normalized EPSC amplitudes monitored at $0.05 \mathrm{~Hz}$ are plotted from nine cells for NHPP-spermine $(\bigcirc)$ and seven cells for JSTX-3 (๑). Application of both drugs caused $\sim 20 \%$ reduction of the normalized EPSC amplitudes when monitored at $0.05 \mathrm{~Hz}$. By contrast, $\sim 70-80 \%$ reduction was observed in the case of NHPPspermine at the same dose when test stimuli were applied at $1 \mathrm{~Hz}(\triangle, n=$ 6). After a stable baseline was obtained at a holding potential of $-60 \mathrm{mV}$, NHPP-spermine and JSTX-3 were applied at 10 and $1 \mu \mathrm{M}$, respectively, during the time indicated by a bar $(10 \mathrm{~min})$. Onset and offset times of drug application are shown in the graph (bar). It took $\sim 2 \min$ for the solution transmitter release, we selected two blockers, $\mathrm{Ni}^{2+}(50 \mu \mathrm{M}$, for potential T-type) and nimodipine (10 $\mu \mathrm{M}$, for L-type), to test the contribution of VSCCs to LTP induction. Although these blockers had no effect on the shape of EPSPs, the induction of LTP was significantly decreased $(104.5 \pm 6.3 \%$ at $30 \mathrm{~min} ; p=0.0348$, unpaired $t$ test; $p=0.0083$, ANOVA; $n=8$ ) (Fig. $2 B, \boldsymbol{\nabla}$ ). Thus, VSCCs are responsible for $\mathrm{Ca}^{2+}$ entry in LTP induction.

\section{LTP is not dependent on NMDA receptor activation}

Another possible source of $\mathrm{Ca}^{2+}$ is the NMDA receptor, an ionotropic glutamate receptor subtype. However, addition of D-APV $(50 \mu \mathrm{M})$, a selective NMDA receptor antagonist, during the induction protocol showed that LTP induction was independent of NMDA receptor activation (for D-APV, $145.6 \pm 18.8 \%$ at $30 \mathrm{~min} ; n=7$ ) (Fig. $2 C, \triangle$ ). Similarly, a nonselective mGlu receptor antagonist $(S)$-MCPG $(1 \mathrm{~mm})$ was ineffective in blocking LTP induction [for $(S)-\mathrm{MCPG}, 124.7 \pm 10.0 \%$ at $30 \mathrm{~min} ; n=$ 18; data not shown]. Thus, it is also likely that $\mathrm{mGlu}$ receptors are not involved in LTP induction. However, the $(S)$-MCPG only nonspecifically blocks group I and group II mGlu receptors, so that the use of more specific antagonists might be needed to clarify the roles of mGlu receptors.

\section{Striatal cholinergic interneurons possess $\mathrm{Ca}^{2}$ - permeable AMPA receptors}

Recent immunocytochemical studies suggested the presence of $\mathrm{Ca}^{2+}$-permeable AMPA receptors in the striatal cholinergic neuron (Chen et al., 1996; Bernard et al., 1997). Therefore, $\mathrm{Ca}^{2+}$ entry through the $\mathrm{Ca}^{2+}$-permeable AMPA receptors must play a significant part in LTP induction. Consistent with the previous studies, voltage-clamp recordings in the presence of D-APV and BMI in the bath and spermine $(0.1 \mathrm{~mm})$ in the pipette revealed that the current-voltage $(I-V)$ relationship of EPSCs was inward rectifying, as exemplified in Figure 3, $A a$ and $A b$. Rectification index (R.I.), calculated as the ratio of chord conductance at +40 $\mathrm{mV}$ and $-70 \mathrm{mV}$, was estimated as $0.54 \pm 0.01(n=20)$. Among the 20 cells tested, 11 cells showed an R.I. of $<0.57$, that is, the value when the $I-V$ relationship is linear (mean \pm SEM, $0.25 \pm$ $0.04 ; n=11$ ) (Fig. $3 B a$ ). The $I-V$ relationship of normalized peak EPSC amplitudes obtained from all 20 cells showed a clear inward rectification $(n=20)$ (Fig. $3 B b)$. Thus, the cholinergic interneurons as a whole possess $\mathrm{Ca}^{2+}$-permeable AMPA receptors. We next tested the effects of two receptor blockers, NHPP-spermine $(10 \mu \mathrm{M})$ and JSTX-3 $(1 \mu \mathrm{M})$ on EPSCs. Both are known to block the $\mathrm{Ca}^{2+}$-permeable receptors in a use-dependent manner (Washburn and Dingledine, 1996; Iino et al., 1996). Thus, monitoring of EPSC amplitudes by test stimuli itself affects the EPSC amplitudes. Indeed, application of NHPP-spermine $(10 \mu \mathrm{M})$ suppressed the amplitude of EPSCs evoked by test stimuli at a frequency of $0.05 \mathrm{~Hz}$ by $\sim 20 \%$ at a holding potential of $-60 \mathrm{mV}$, whereas $70-80 \%$ suppression was observed when the test stimuli were given at a frequency of $1.0 \mathrm{~Hz}$ (Fig. $3 C, \bigcirc$ and $\triangle$, respec-

to arrive at the recording chamber in our experimental configuration. Test stimuli were elicited at either 0.05 or $1 \mathrm{~Hz}$. Differences of EPSC amplitudes between before and after NHPP-spermine at $0.05 \mathrm{~Hz}$ were statistically significant at $14,16,17,20,29$, and 33 min after the start of bath application (paired $t$ test, $p<0.05 ; n=9$ ). Differences of EPSC amplitudes between before and after NHPP-spermine at $1.0 \mathrm{~Hz}$ were statistically significant throughout $5 \mathrm{~min}$ after the start of bath application $(p<$ 0.05 at $5 \mathrm{~min}, p<0.01$ thereafter, paired $t$ test; $n=6$ ). Differences between the experiment with NHPP-spermine at $0.05 \mathrm{~Hz}$ and that of 1.0 $\mathrm{Hz}$ were statistically significant ( $p<0.0001$, ANOVA). 
tively). JSTX-3 $(10 \mu \mathrm{M})$ also caused $\sim 20 \%$ reduction of the evoked EPSCs at $0.05 \mathrm{~Hz}$ (Fig. $C, 0$ ). What is more, HFS caused immediate and almost complete blockage of the receptor channels in 7 of 14 cells tested (data not shown). Accordingly, it is not feasible to study the roles of the receptors in LTP induction by using these antagonists. However, it must be noted that there remains a possibility that the $\mathrm{Ca}^{2+}$-permeable AMPA receptors contribute to LTP induction in a certain population of cholinergic interneurons.

\section{DA receptor activation is required for LTP induction}

It is known that cholinergic interneurons contain $\mathrm{D}_{2}$ and $\mathrm{D}_{5} \mathrm{DA}$ receptors (Bergson et al., 1995; Yan and Surmeier, 1997; Aosaki et al., 1998; Pisani et al., 2000) that produce a complex modulation on the cholinergic tone in the striatum (Di Chiara et al., 1994). It is also known that tetanic stimulation of corticostriatal fibers produced a significant but transient increase of DA release in the striatum (Calabresi et al., 1995). Therefore, we proceeded to use antagonists of these receptors to investigate the influence of DA in LTP induction. However, one concern regarding the use of the DA receptor antagonists such as $\mathrm{SCH} 23390$, a $\mathrm{D}_{1}$-like receptor antagonist, is the possibility that they act on serotonin receptors as well. Therefore we first tested the effects of a mixture of three kinds of serotonin receptor antagonists, ketanserin, RS39604, and methiothepin, on LTP in the cholinergic cells. Ketanserin is known to block 5-HT1A, -r1B, -h1B, -1D, -2A, -2B, $-2 \mathrm{C},-3,-5 \mathrm{~A}$, and -7 receptors (Hoyer et al., 1994; Zgombick et al., 1995). RS39604 blocks specifically 5-HT4 receptor (Hegde et al., 1995). Methiothepin blocks 5-HT1A, -r1B, -h1B, -1D, -1E, -1F, $-2 \mathrm{~A},-2 \mathrm{C},-5 \mathrm{~A},-6$, and -7 receptors (Hoyer et al., 1994; Bard et al., 1996). All of them are known to be effective at a concentration of $1 \mu \mathrm{M}$. Thus, a mixture of these compounds at this concentration would block virtually all 5-HT receptor subtypes. We applied the mixture for 10 min before tetanus and found that HFS caused a lasting potentiation of EPSP in the cholinergic interneurons $(135.7 \pm 28.9 \%$ at $30 \mathrm{~min} ; n=10)$ (Fig. $4 A$, open butterflies). It is therefore reasonable to suppose that serotonin receptors are not involved in LTP induction in the cholinergic interneurons.

We next tested the roles of DA receptors. Tetanic stimulation during bath application of the $\mathrm{D}_{1} / \mathrm{D}_{5} \mathrm{DA}$ receptor antagonist $\mathrm{SCH} 23390(10 \mu \mathrm{M})$, but not the $\mathrm{D}_{2}$ antagonist ( \pm )-sulpiride (10 $\mu \mathrm{M}$ ), was found to block LTP induction entirely (for SCH23390, $103.9 \pm 6.4 \%$ at $30 \mathrm{~min} ; p<0.05$, unpaired $t$ test; $n=15 ; p<$ 0.0001 , ANOVA; $n=15$; for $( \pm)$-sulpiride, $127.6 \pm 8.9 \%$ at 30 $\min ; n=7$ ) (Fig. $4 B$, $\square$ and $\square$, respectively).

The above results suggest that VSCC and DA receptor activation are highly responsible for LTP induction of striatal cholinergic interneurons, whereas NMDA, mGlu, and serotonin receptors seem to have little or no effect. The roles of $\mathrm{Ca}^{2+}$-permeable AMPA receptors may also be crucial for LTP induction, but there is no means to prove it at present.

\section{Disynaptically mediated IPSP is potentiated after HFS}

In a second series of experiments, we examined whether disynaptic IPSP was involved in synaptic plasticity. Current-clamp recordings of striatal cholinergic neurons in a control solution (without BMI) exhibited a large, clearly discernible disynaptic IPSP superimposed on an EPSP (Fig. 5A). This IPSP was $\mathrm{GABA}_{\mathrm{A}}$ receptor mediated, first because its reversal potential was approximately $-60 \mathrm{mV}$ (Fig. $5 A b, B b$ ), which is similar to the equilibrium potential of $\mathrm{Cl}^{-}$of our recording configuration, and second because BMI $(30 \mu \mathrm{M})$ completely and reversibly blocked
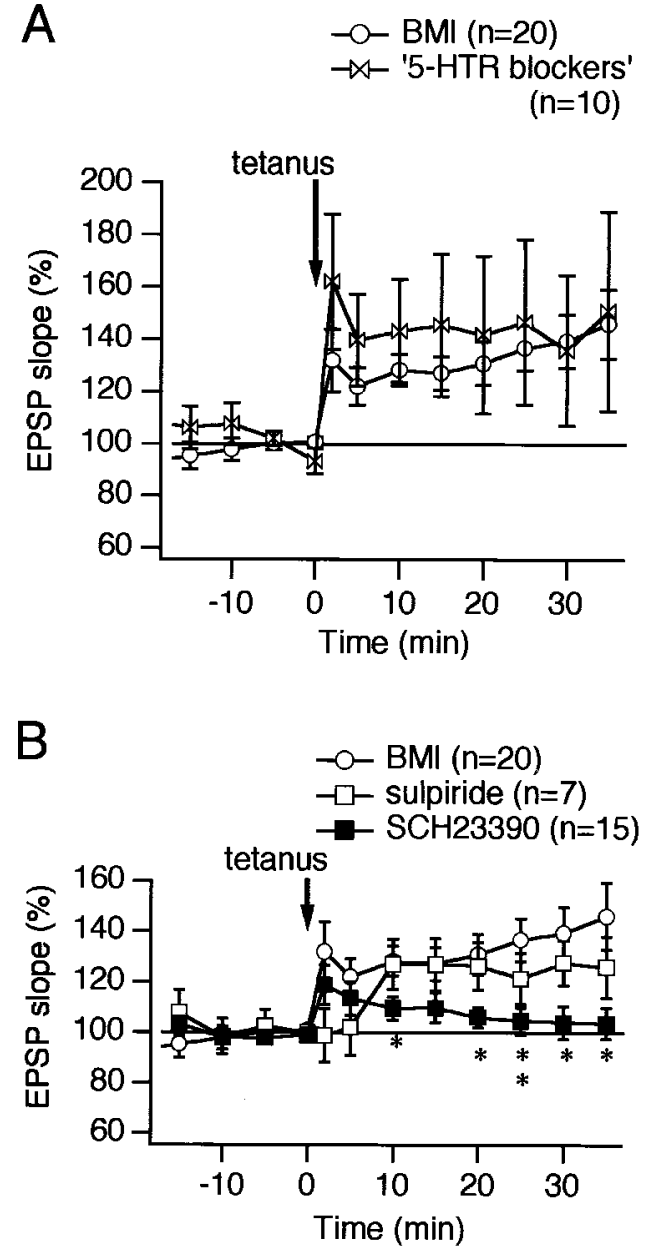

Figure 4. Dopamine D1-like receptor activation is required for LTP induction in the cholinergic interneurons. $A$, A mixture of antagonists for serotonin receptors was applied for the duration of $10 \mathrm{~min}$ before HFS to rule out the involvement of serotonin receptors in LTP induction (open butterflies). The antagonists used were ketanserin (1 $\mu \mathrm{M})$, RS39604 (1 $\mu \mathrm{M})$, and methiothepin $(1 \mu \mathrm{M})$. The mixture covers virtually all of the receptor subtypes. LTP was unaffected even in the presence of the antagonists $(p=0.13$, ANOVA; $n=10)$. $B$, Pretreatment with $( \pm)$ sulpiride $(10 \mu \mathrm{M} ; \square)$ delayed but did not block LTP induction $(p=$ 0.0588 , ANOVA; $n=7)$, whereas treatment with SCH23390 (10 $\mu \mathrm{M} ; \mathbf{\square})$ for 10 min blocked LTP of cortico/thalamostriatal EPSP. Differences between the control and the experiment with SCH23390 were statistically significant 10 and $20 \mathrm{~min}$ after HFS (10, 20, 30, and 35 min after HFS, $p<$ 0.05 , unpaired $t$ test; 25 min after HFS, $p<0.01$, unpaired $t$ test; $p<$ 0.0001 , ANOVA; $n=15)$. Statistical significance was marked by the asterisks on the graph: ${ }^{*} p<0.05,{ }^{*} p<0.01$.

the hyperpolarizing postsynaptic potential (Figs. $1 C, 5 A c$ ). The IPSP amplitude was a function of the driving force of the equilibrium potential; hence before and after tetanus amplitudes were compared at a resting membrane potential range of -58.5 to $-62.5 \mathrm{mV}$ (Fig. $5 B$ ). Interestingly, HFS caused a lasting potentiation of the disynaptic IPSP (152.4\% at $30 \mathrm{~min}$ ) (Fig. $5 B a$ ).

Then, is this IPSP actually hyperpolarizing in a physiological condition? This question is important when we consider its physiological roles. We then proceeded to determine the equilibrium potential for $\mathrm{Cl}^{-}$in a separate experiment. The gramicidin perforated patch-clamp technique (Abe et al., 1994) estimated the actual equilibrium potential for $\mathrm{Cl}^{-}$in the striatal cholinergic interneurons of the mouse to be $-72 \mathrm{mV}(-88-62 \mathrm{mV} ; n=3)$, 


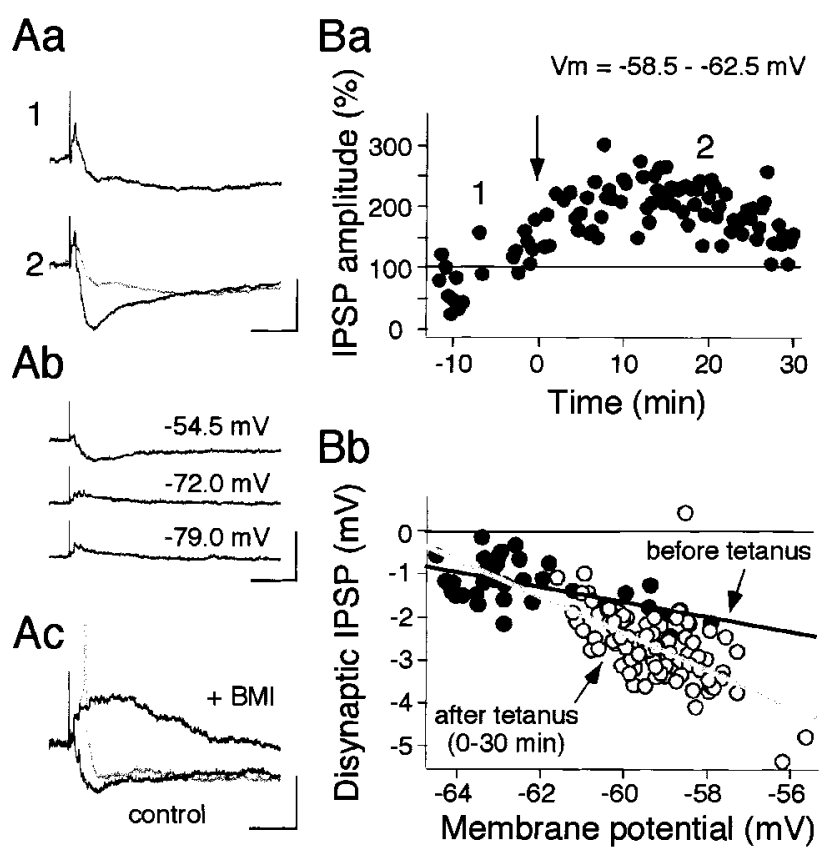

Figure 5. Long-term potentiation of disynaptic IPSP in cholinergic neurons. $A a$, Evoked postsynaptic potentials by a test stimulus $(250 \mu \mathrm{A}, 100$ $\mu \mathrm{sec})$ containing a large IPSP before (1) and after (2) HFS $(100 \mathrm{~Hz}, 1$ $\mathrm{sec})$. Note that the IPSP was significantly augmented. $A b$, Reversal of disynaptic IPSP. Postsynaptic potentials were recorded at the membrane potential shown beside each trace. Ac, BMI $(30 \mu \mathrm{M})$ abolished the IPSP and unmasked a large depolarizing plateau potential $(+B M I)$, which occasionally triggered an action potential (gray trace). Calibration: $1 \mathrm{mV}$ $(A a), 10 \mathrm{mV}(A b), 5 \mathrm{mV}(A c) ; 100 \mathrm{msec}(A a, A b, A c)$. Ba, LTP of disynaptic IPSP. Peak IPSP amplitudes, measured from onset to peak at membrane potentials of -58.5 to $-62.5 \mathrm{mV}$, are plotted against time for a single cell. IPSPs evoked at membrane potentials outside the range of -58.5 to $-62.5 \mathrm{mV}$ were omitted from the graph. $B b$, IPSP amplitudes are plotted as a function of membrane potential, at which each IPSP was obtained before $(\bullet)$ and after $(\bigcirc)$ tetanic stimulation, and are fitted with a linear regression. The line fit for data before tetanus (black line) intersects the line for data after tetanus ( gray line) at approximately -63 $\mathrm{mV}$, which is close to the equilibrium potential of $\mathrm{Cl}^{-}(-59 \mathrm{mV})$ in this recording configuration. Note that evoked IPSPs before tetanus are smaller than those after tetanus at around resting membrane potentials of this cell (approximately $-60 \mathrm{mV}$ ).

showing that IPSPs are also hyperpolarizing in physiological conditions (data not shown).

\section{A long-term increase in the occurrence rate of disynaptic IPSC}

To examine this LTP of disynaptic IPSP in more detail, the cells were voltage clamped to $\sim 0 \mathrm{mV}$, so that the potential EPSCs were negligible. IPSCs were evoked at a latency of $10.0 \pm 1.0$ msec $(n=11)$ after the EPSCs (Fig. $6 A)$. Both BMI and CNQX completely abolished the IPSC, confirming once more that the IPSC is disynaptic and GABAergic (data not shown). HFS increased the probability of IPSC occurrence, but not the individual amplitude of each unitary IPSC. For example, in one cell shown in Figure $6 A$, the occurrence rate of a $8.3 \mathrm{msec}$ latency IPSC that occurred only once before tetanus (indicated by a small arrow) increased from 0.13 to 0.58 after tetanus, but its amplitude remained almost the same (before, $44.7 \mathrm{pA}$; after, $40.7 \pm 12.7$ pA; mean $\pm \mathrm{SD}$ ) (Fig. $6 \mathrm{Ca}, \mathrm{Cb}$ ). Furthermore, HFS recruited many new IPSCs as shown in Figure $6 A$ (after tetanus). As a result, the amplitude of ensemble IPSCs, which consist of multiple unitary IPSCs, greatly increased after the tetanus. As shown in Figure $6 B b$, the averaged trace calculated from all the traces during a $10 \mathrm{~min}$ period before tetanus contained virtually no IPSC, but the trace averaged 25-35 min after the tetanus showed a significantly large averaged ensemble IPSC. Figure $7 A$ confirmed this by averaging the results taken from nine cells. The amplitude of the polysynaptic ensemble IPSCs-the highest peak occurring within $50 \mathrm{msec}$ after stimulation-increased by $252.3 \pm$ $76.2 \%$ at 30 min after tetanus ( $n=9 ; p<0.0001$, unpaired $t$ test $)$ (Fig. $7 A$ ). This augmentation was not caused by the increase in the amplitudes of unitary IPSCs but by their occurrence rates, as shown in Figure $7 B(n=9)$. These results suggest that LTP of the IPSCs was solely presynaptically mediated and that HFS of cortico/thalamostriatal fibers raised the excitability of the yet unidentified GABA neurons within the striatum, increasing the probability of spike generation of them (GABA neurons) (see Fig. 9).

\section{Simultaneously occurring LTP of EPSP and disynaptic IPSP}

HFS of cortico/thalamostriatal fibers could induce LTP of both glutamatergic EPSP and disynaptic GABAergic IPSP in the cholinergic interneurons (Fig. 8). Now, if both of these were induced simultaneously, the potentiated IPSP would block spike generation triggered by the EPSP. We found this to be the case (Fig. 8, 3 and 4, open arrows). In the absence of BMI, HFS reliably induced LTP of the cortico/thalamostriatal EPSP $(151.7 \pm 19.3 \%$; $n=12$ ) but also increased the amplitude of the disynaptic IPSP (Fig. 8, 2 and 3, arrows). This enhanced IPSP effectively suppressed spike generation, or at least delayed its timing, as shown in Figure 8 (3 and 4, open arrows).

\section{DISCUSSION}

Although the importance of ACh in the learning and memory processes has been pointed out in the striatum as well as the cerebral cortex, not a single electrophysiological study has been made to test whether the cholinergic neurons themselves undergo long-term synaptic changes after HFS. The aim of this study therefore was to answer this question using the striatal cholinergic interneurons and to elucidate the mechanism of synaptic plasticity in them. The results obtained here indicate the following. (1) Electrical stimulation of cortico/thalamostriatal pathways frequently evokes a depolarizing and hyperpolarizing postsynaptic potential in the cholinergic interneurons that is composed of a cortico/thalamostriatal glutamatergic EPSP and an intrastriatally evoked disynaptic GABAergic IPSP, respectively. (2) Tetanic stimulation induces LTP of the EPSP, which facilitates spike firing in the cholinergic interneurons. (3) This LTP induction is dependent on a postsynaptic rise in $\mathrm{Ca}^{2+}$ and dopamine $\mathrm{D}_{5}$ receptor activation. (4) Tetanic stimulation also induces an increase in the occurrence rate of the disynaptic IPSP, which suppresses spike firing in the cholinergic interneurons.

We used brain slices cut sagittally instead of coronally to observe electrically evoked postsynaptic potentials, because electrical stimulation of subcortical white matter usually evoked very small postsynaptic potentials in the coronal slices, whereas the same stimulation protocol reliably elicited large responses in the striatal cholinergic interneurons. This coincides with previous demonstrations that cholinergic interneurons of the striatum receive a strong glutamatergic input from the CM-Pf of the thalamus and, to a lesser extent, from the cerebral cortex (Lapper and Bolam, 1992; Thomas et al., 2000). We reasoned that dorsoanteriorly projecting thalamostriatal fibers might have been largely 


\begin{abstract}
Figure 6. LTP of disynaptic IPSC is mediated by an increase in the occurrence rate of GABA release. $A$, Sample traces before (top 3 traces) and after tetanus (bottom 4 traces). Membrane conductance was monitored with a test pulse $(2 \mathrm{mV}, 3$ $\mathrm{msec}$ ) throughout the experiment. IPSCs were obtained at a holding membrane potential of $0 \mathrm{mV}$, at which EPSCs were nullified. Before tetanus, an IPSC indicated by a small arrow was recorded only once. After tetanus, multiple IPSCs were evoked in almost all sweeps, including the same IPSC as the one seen before tetanus. Calibration: $50 \mathrm{pA}, 50 \mathrm{msec} . \mathrm{Ba}$, The afferent fibers were tetanized at time 0 ( $a r$ row). Peak ensemble IPSC amplitudes measured within $50 \mathrm{msec}$ after test stimulus are plotted against time for a single cell. BMI, applied during the time indicated by the gray bar, abolished all IPSCs. Averaged sweeps recorded at the times indicated $(1,2)$ are shown in $B b$. Calibration: $10 \mathrm{pA}, 20 \mathrm{msec}$. $\mathrm{Ca}$, Comparison of the occurrence rate of the IPSC indicated by an arrow in $A$ between before and after tetanus. The occurrence rate dramatically increased after tetanus. $\mathrm{Cb}$, Amplitude of the IPSC remained almost the same.
\end{abstract}
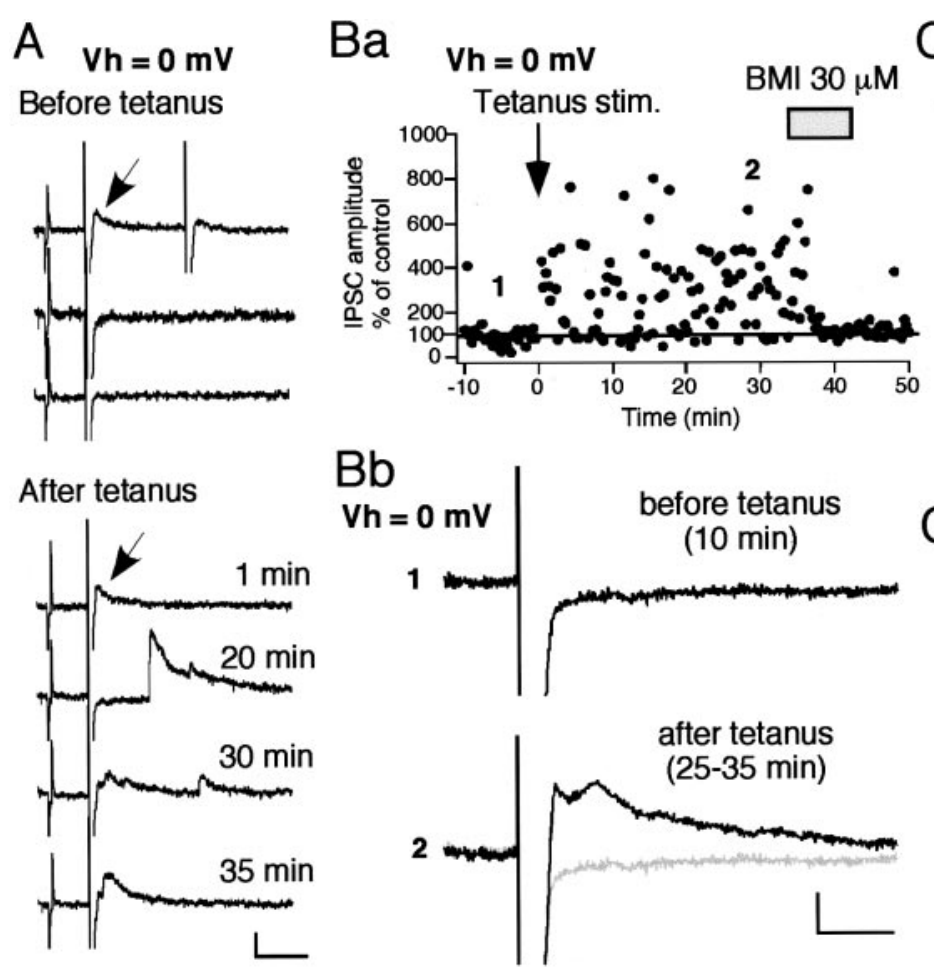

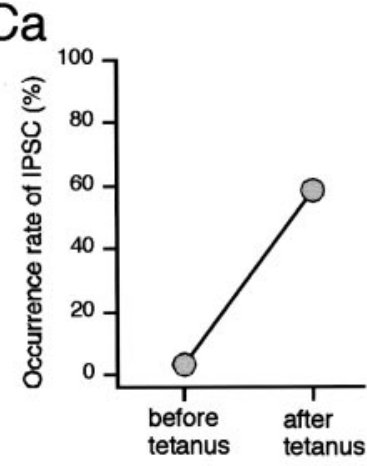

$\mathrm{Cb}$

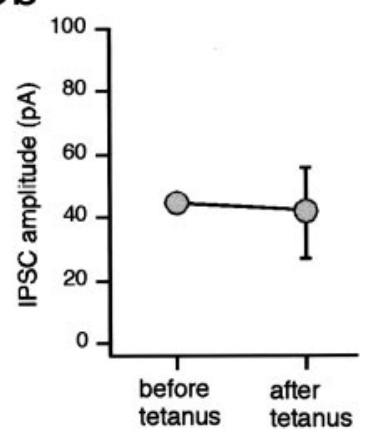

severed in the coronal slices but spared in the sagittal slices. We found that electrical stimulation usually evoked an EPSP with a short latency, but that the increment of stimulus intensity gradually revealed a hyperpolarizing component that superposed and dampened the peak of the EPSPs. The latter was proved to be a disynaptically evoked GABAergic IPSP because (1) it was completely blocked by bicuculline; (2) when the EPSP was suppressed by bath application of D-APV and CNQX, the IPSP also disappeared; and (3) when the membrane potential was voltage clamped to $\sim 0 \mathrm{mV}$, there appeared a later-onset GABAergic IPSC in response to electrical stimulation. Similar cortically driven disynaptic IPSP was reported in early electrophysiological studies to occur in the striatal medium spiny neurons in response to corticostriatal stimulation (Buchwald et al., 1973; Herrling, 1984; Wilson, 1986; Kita, 1993).

Tetanic stimulation of the subcortical white matter induced LTP of EPSPs in the cholinergic interneurons. This LTP induction required a rise in postsynaptic $\mathrm{Ca}^{2+}$ and dopamine $\mathrm{D}_{5}$ receptor activation. The source of $\mathrm{Ca}^{2+}$, although not exclusive, was the opening of voltage-sensitive $\mathrm{Ca}^{2+}$ channels. The cholinergic interneurons contained a significant amount of $\mathrm{Ca}^{2+}$ permeable AMPA receptors. Thus, there is still room for the possibility that $\mathrm{Ca}^{2+}$ entry through the receptor channels makes a significant contribution. Also, the cholinergic neurons are known to contain both $\mathrm{D}_{2}$ and $\mathrm{D}_{5}$ DA receptors, among which only $\mathrm{D}_{5}$ DA receptors were indispensable to LTP induction. An anatomical study demonstrated that antibodies to $\mathrm{D}_{5}$ DA receptors predominantly labeled the dendritic shafts and somata of the striatal cholinergic interneurons, whereas $\mathrm{D}_{1}$ DA receptors were distributed prominently in the dendritic spines of the striatal medium spiny neurons in the rhesus monkey (Bergson et al., 1995). Thus, a selective role for $D_{5}$ in modulating axonal input to, or releasing of ACh from, these neurons is strongly suggested. Activation of $\mathrm{D}_{1}$-class $\mathrm{DA}$ receptors has multiple effects. It depolarizes the cholinergic interneurons by suppressing the resting $\mathrm{K}^{+}$ conductance and opening nonselective cation channels (Aosaki et al., 1998). It also reduces $\mathrm{N}$ - and P-type $\mathrm{Ca}^{2+}$ currents but enhances L-type currents in the rat medium spiny neurons (Surmeier et al., 1995). Moreover, it was reported that the striatum contained a $\mathrm{D}_{1}$-class receptor coupled to inositol phosphate production and mobilization of intracellular $\mathrm{Ca}^{2+}$, which is distinct from the classic $D_{1}$ receptor that is coupled to stimulation of cAMP formation (Mahan et al., 1990; Undie et al., 1994). Thus, it is possible that $D_{5}$ receptor activation might somehow facilitate intracellular $\mathrm{Ca}^{2+}$ elevation and eventually contribute to LTP induction. By contrast, $\mathrm{D}_{2}$ DA receptors were reported to suppress N-type $\mathrm{Ca}^{2+}$ currents (Yan et al., 1997) and to cause presynaptic inhibition of both GABAergic and muscarinic inhibitory potentials in the striatal cholinergic interneurons (Pisani et al., 2000). However, as far as the LTP induction is concerned, $D_{2}$ receptor may not play a significant role in this form of synaptic plasticity. This was also confirmed in our preliminary experiments using mice lacking $\mathrm{D}_{2}$ DA receptors $(n=5$; data not shown).

Previous studies have shown that TANs, presumptive striatal cholinergic interneurons, acquire DA-dependent conditioned pause responses in reaction to sensory stimuli that have been associated with reward during sensorimotor learning (Aosaki et al., 1994a,b, 1995). However, it has not been determined whether this conditioned response results from an alteration of synaptic efficacy of the TANs themselves or of other neurons in the striatum or other parts of the brain. Our study unequivocally demonstrates for the first time that striatal cholinergic interneurons themselves actively participate in the memory process by showing long-term changes in synaptic efficacy. Bennett and Wilson $(1998,1999)$ recently claimed that a spike triggered by synaptic inputs and subsequent AHP might underlie the pause response of the TANs on the grounds that AHP after a spike triggered by synaptic inputs was significantly longer than the one after spontaneous discharge and that this prolongation was 


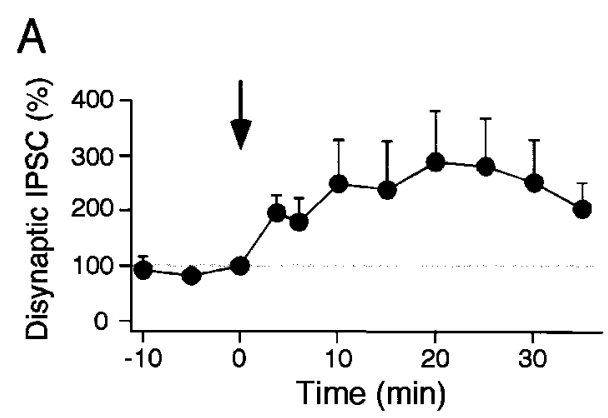

$\mathrm{Ba}$

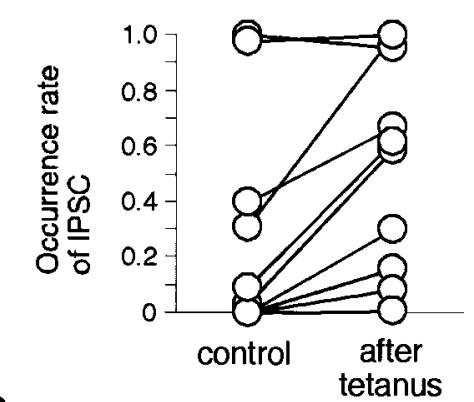

$\mathrm{Bb}$

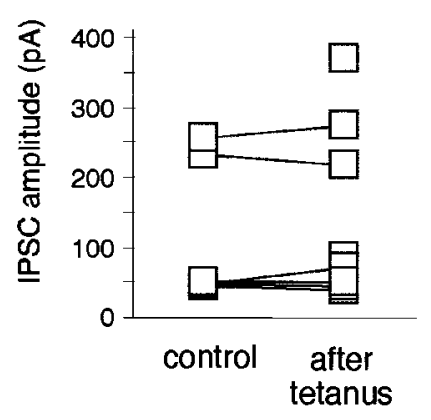

Figure 7. LTP of disynaptic IPSC is mainly presynaptic. $A$, Average data $(n=7)$ for LTP of the disynaptic ensemble IPSC. Ba, Occurrence rate of IPSCs increased after tetanus (paired $t$ test, $p<0.01 ; n=10$ ). Ten IPSCs were identified in each sweep in seven cells, and the occurrence rates of each IPSC were compared between before and after tetanus. $B b$, IPSC amplitudes did not change significantly after tetanus.

proved to be mediated by $D_{1} / D_{5}$ receptor activation, probably via simultaneous release of DA triggered by test stimulus. Indeed, consistent with their findings, the interspike interval (ISI) of the spontaneously firing TANs was significantly shorter than the pause in the conditioned response (Aosaki et al., 1995). However, this hypothesis presupposes that a spike faithfully occurs after the presentation of a conditioned stimulus. Our finding therefore upholds their hypothesis on the condition that DA-dependent LTP should occur in the cholinergic neurons per se.

The fact that a spike did not always precede the pause in the conditioned response, however, suggests the existence of an additional mechanism. Simultaneously occurring long-lasting enhancement of disynaptically evoked IPSPs observed in this study could therefore play an important role in producing a pause after learning, because it effectively suppressed the spike generation and prolonged the ISI. Yan and Surmeier (1997) proposed the second hypothesis: that repeated pairing of the rewarddependent dopaminergic input and sensory-linked GABAergic input might lead to a lasting potentiation of GABAergic responses. This idea is based on the observation that $\mathrm{Zn}^{2+}$ sensitive $\mathrm{GABA}_{\mathrm{A}}$ currents in the striatal cholinergic interneurons

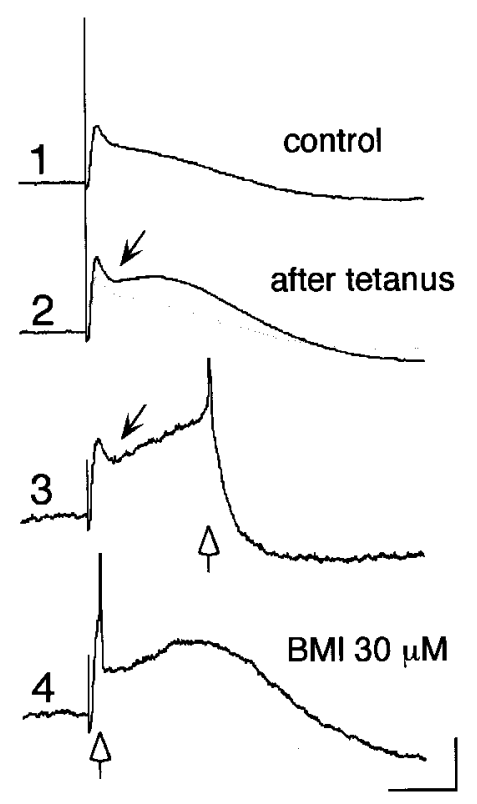

Figure 8. Simultaneous LTP of EPSP and disynaptic IPSP. Evoked synaptic potentials before $(1)$ and 45 min after $(2,3)$ tetanic stimulation $(100 \mathrm{~Hz}, 1 \mathrm{sec}, 500 \mu \mathrm{A}, 250 \mu \mathrm{sec})$ and after BMI application (4). Note that EPSP as well as a hyperpolarizing component (arrow) was significantly potentiated (2) and that a spike was generated occasionally after hyperpolarizing deflection (3). BMI abolished the hyperpolarizing component, so that a spike was triggered synchronously at the timing of a test stimulus (4). Open arrows in 3 and 4 indicate the timing of spike generation. Calibration: $5 \mathrm{mV}, 50 \mathrm{msec}$.

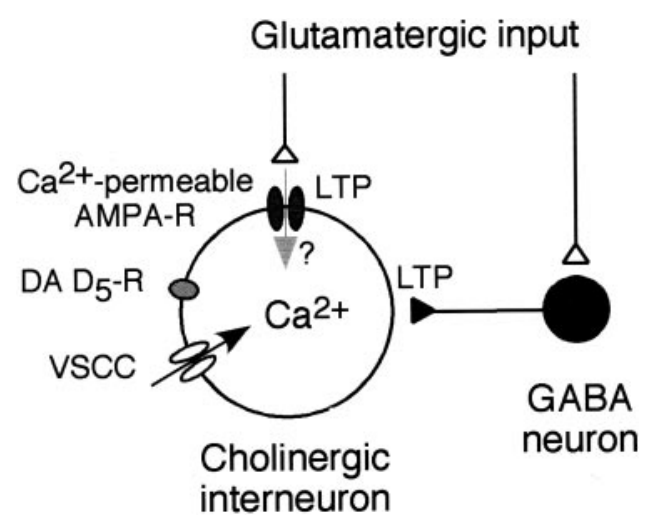

Figure 9. Diagram showing the circuitry within the striatum. Recordings were made from cholinergic interneurons. LTP of glutamatergic EPSP and long-term facilitation of disynaptic IPSCs occur in the cholinergic interneuron. LTP of EPSP requires intracellular rise in $\mathrm{Ca}^{2+}$ concentration. LTP induction is dependent on activation of voltage-sensitive $\mathrm{Ca}^{2+}$ channels $(V S C C)$ and $\mathrm{DA} \mathrm{D}_{5}$ receptor. $\mathrm{Ca}^{2+}$-permeable AMPA receptors may also contribute to the LTP of EPSP in some cells.

were reversibly enhanced through $\mathrm{D}_{5}$ DA receptor activation. Although our experiments did not test this hypothesis directly, the results obtained here showed that the amplitudes of IPSCs remained unchanged, indicating that LTP of IPSPs observed in our experiments was mediated presynaptically. Further study is needed to determine the postsynaptic changes in inhibitory synapses. We conclude that the simultaneous LTP of EPSPs and disynaptic IPSPs underlies the conditioned response of the TANs.

Interestingly, a recent work in behaving monkeys has demonstrated that the inactivation of CM-Pf by muscimol injections 
selectively diminished the pause and rebound facilitatory responses of the TANs, whereas the initial spike firing was largely intact (Matsumoto et al., 2001). Thus, the initial spike firing might be evoked mainly by cortical inputs, possibly through LTP of corticostriatal EPSPs, whereas the pause responses might be evoked indirectly by thalamostriatal inputs through disynaptically mediated GABAergic inhibition.

As for the GABA neurons that send inhibitory inputs to the cholinergic interneurons, a potential candidate is the medium spiny projection neuron, of which local axon collaterals were demonstrated by anatomical studies to make synaptic contacts with the cholinergic interneurons (Bolam et al., 1986; Kita, 1993). In addition, it has been extensively reported that this neuron type produces LTP under certain conditions (Calabresi et al., 1992, 1996; Wickens et al., 1996; Charpier and Deniau, 1997). Little is known about other types of GABA neurons except that the parvalbumin-containing GABA interneuron makes no synaptic contact with the cholinergic interneurons (Bolam et al., 1986; Kita et al., 1990; Chang and Kita, 1992; Kita, 1993).

Because muscarinic ACh receptor activation stabilizes the up and down states of the membrane potentials of the medium spiny projection neurons (Akins et al., 1990; Stern et al., 1998) and promotes LTP in the striatal projection neurons (Calabresi et al., 2000), activity-dependent synaptic changes of the cholinergic interneurons should influence the firing probability of surrounding projection neurons (Graybiel et al., 1994). Disruption of DA-dependent synaptic plasticity in the striatal cholinergic neurons therefore might be a cellular substrate in the subcortical dementia and motor dysfunction seen in Parkinson's disease.

\section{REFERENCES}

Abe Y, Furukawa K, Itoyama Y, Akaike N (1994) Glycine response in acutely dissociated ventromedial hypothalamic neuron of the rat: new approach with gramicidin perforated patch-clamp technique. J Neurophysiol 72:1530-1537.

Akins PT, Surmeier DJ, Kitai ST (1990) Muscarinic modulation of a transient $\mathrm{K}^{+}$conductance in rat neostriatal neurons. Nature 344:240-242.

Aosaki T, Graybiel AM, Kimura M (1994a) Effect of the nigrostriatal dopamine system on acquired neural responses in the striatum of behaving monkeys. Science 265:412-415.

Aosaki T, Tsubokawa H, Ishida A, Watanabe K, Graybiel AM, Kimura M (1994b) Responses of tonically active neurons in the primate's striatum undergo systematic changes during behavioral sensorimotor conditioning. J Neurosci 14:3969-3984.

Aosaki T, Kimura M, Graybiel AM (1995) Temporal and spatial characteristics of tonically active neurons of the primate's striatum. J Neurophysiol 73:1234-1252.

Aosaki T, Kiuchi K, Kawaguchi Y (1998) Dopamine D1-like receptor activation excites rat striatal large aspiny neurons in vitro. J Neurosci 18:5180-5190.

Bard JA, Kucharewicz SA, Zgombick JM, Weinshank RL, Branchek TA, Cohen ML (1996) Differences in ligand binding profiles between cloned rabbit and human 5-HT1D alpha and 5-HT1D beta receptors: ketanserin and methiothepin distinguish rabbit 5-HT1D receptor subtypes. Naunyn Schmiedebergs Arch Pharmacol 354:237-244.

Bennett BD, Wilson CJ (1998) Synaptic regulation of action potential timing in neostriatal cholinergic interneurons. $J$ Neurosci 18:8539-8549.

Bennett BD, Wilson CJ (1999) Spontaneous activity of neostriatal cholinergic interneurons in vitro. J Neurosci 19:5586-5596.

Bergson C, Mrzljak L, Smiley JF, Pappy M, Levenson R, Goldman-Rakic PS (1995) Regional, cellular, and subcellular variations in the distribution of $\mathrm{D}_{1}$ and $\mathrm{D}_{5}$ dopamine receptors in primate brain. J Neurosci 15:7821-7836.

Bernard V, Somogyi P, Bolam JP (1997) Cellular, subcellular, and subsynaptic distribution of AMPA-type glutamate receptor subunits in the neostriatum of the rat. J Neurosci 17:819-833.

Bolam JP, Ingham CA, Izzo PN, Levey AI, Rye DB, Smith AD, Wainer BH (1986) Substance P-containing terminals in synaptic contact with cholinergic neurons in the neostriatum and basal forebrain: a double immunocytochemical study in the rat. Brain Res 397:279-289.
Buchwald NA, Price DD, Vernon L, Hull CD (1973) Caudate intracellular response to thalamic and cortical inputs. Exp Neurol 38:311-323.

Calabresi P, Pisani A, Mercuri NB, Bernardi G (1992) Long-term potentiation in the striatum is unmasked by removing the voltagedependent magnesium block of NMDA receptor channels. Eur J Neurosci 4:929-935.

Calabresi P, Fedele E, Pisani A, Fontana G, Mercuri NB, Bernardi G, Raiteri M (1995) Transmitter release associated with long-term synaptic depression in rat corticostriatal slices. Eur $J$ Neurosci 7:1889-1894.

Calabresi P, Pisani A, Mercuri NB, Bernardi G (1996) The corticostriatal projection: from synaptic plasticity to dysfunctions of the basal ganglia. Trends Neurosci 19:19-24.

Calabresi P, Centonze D, Gubellini P, Pisani A, Bernardi G (2000) Acetylcholine-mediated modulation of striatal function. Trends Neurosci 23:120-126.

Chang HT, Kita H (1992) Interneurons in the rat striatum: relationships between parvalbumin neurons and cholinergic neurons. Brain Res 574:307-311.

Chao TI, Alzheimer C (1995) Do neurons from rat neostriatum express both a TTX-sensitive and a TTX-insensitive slow Na ${ }^{+}$current? J Neurophysiol 74:934-941.

Charpier S, Deniau JM (1997) In vivo activity-dependent plasticity at cortico-striatal connections: evidence for physiological long-term potentiation. Proc Natl Acad Sci USA 94:7036-7040.

Chen Q, Veenman CL, Reiner A (1996) Cellular expression of ionotropic glutamate receptor subunits on specific striatal neuron types and its implication for striatal vulnerability in glutamate receptor-mediated excitotoxicity. Neuroscience 73:715-731.

Di Chiara G, Morelli M, Consolo S (1994) Modulatory functions of neurotransmitters in the striatum: ACh/dopamine/NMDA interactions. Trends Neurosci 17:228-233.

Graybiel AM, Aosaki T, Flaherty AW, Kimura M (1994) The basal ganglia and adaptive motor control. Science 265:1826-1831.

Hegde SS, Bonhaus DW, Johnson LG, Leung E, Clark RD, Eglen RM (1995) RS 39604: a potent, selective and orally active 5-HT4 receptor antagonist. Br J Pharmacol 115:1087-1095.

Herrling PL (1984) Evidence for GABA as the transmitter for early cortically evoked inhibition of cat caudate neurons. Exp Brain Res 55:528-534.

Hoyer D, Clarke DE, Fozard JR, Hartig PR, Martin GR, Mylecharane EJ, Saxena PR, Humphrey PP (1994) International Union of Pharmacology classification of receptors for 5-hydroxytryptamine (serotonin). Pharmacol Rev 46:157-203.

Iino M, Koike M, Isa T, Ozawa S (1996) Voltage-dependent blockage of $\mathrm{Ca}^{2+}$-permeable AMPA receptors by Joro spider toxin in cultured rat hippocampal neurones. J Physiol (Lond) 496:431-437.

Kawaguchi Y (1992) Large aspiny cells in the matrix of the rat neostriatum in vitro: physiological identification, relation to the compartments and excitatory postsynaptic currents. J Neurophysiol 67:1669-1682.

Kimura M, Rajkowski J, Evarts E (1984) Tonically discharging putamen neurons exhibit set-dependent responses. Proc Natl Acad Sci USA 81:4998-5001.

Kimura M, Kato M, Shimazaki H (1990) Physiological properties of projection neurons in the monkey striatum to the globus pallidus. Exp Brain Res 82:672-676.

Kita H (1993) GABAergic circuits of the striatum. Prog Brain Res 99:51-71.

Kita H, Kosaka T, Heizmann CW (1990) Parvalbumin-immunoreactive neurons in the rat neostriatum: a light and electron microscopic study. Brain Res 536:1-15.

Lapper SR, Bolam JP (1992) Input from the frontal cortex and the parafascicular nucleus to cholinergic interneurons in the dorsal striatum of the rat. Neuroscience 51:533-545.

Mahan LC, Burch RM, Monsma FJ, Sibley DR (1990) Expression of striatal $\mathrm{D}_{1}$ dopamine receptors coupled to inositol phosphate production and $\mathrm{Ca}^{2+}$ mobilization in Xenopus oocytes. Proc Natl Acad Sci USA 87:2196-2200.

Matsumoto N, Minamimoto T, Graybiel AM, Kimura M (2001) Neurons in the thalamic CM-Pf complex supply neurons in the striatum with information about behaviorally significant sensory events. J Neurophysiol 85:960-976.

Pisani A, Bonsi P, Centonze D, Calabresi P, Bernardi G (2000) Activation of D2-like dopamine receptors reduces synaptic inputs to striatal cholinergic interneurons. J Neurosci 20:RC69 (1-6).

Prado-Alcalá RA (1985) Is cholinergic activity of the caudate nucleus involved in memory? Life Sci 37:2135-2142.

Salmon DP, Butters N (1995) Neurobiology of skill and habit learning. Curr Opin Neurobiol 5:184-190.

Schultz W, Apicella P, Ljungberg T (1993) Responses of monkey dopamine neurons to reward and conditioned stimuli during successive steps of learning a delayed response task. J Neurosci 13:900-913.

Stern EA, Jaeger D, Wilson CJ (1998) Membrane potential synchrony of simultaneously recorded striatal spiny neurons in vivo. Nature 394:475-478. 
Surmeier DJ, Bargas J, Hemmings HC, Nairn AC, Greengard P (1995) Modulation of calcium currents by a $\mathrm{D}_{1}$ dopaminergic protein kinase/ phosphatase cascade in rat neostriatal neurons. Neuron 14:385-397.

Suzuki T, Miura M, Nishimura K, Aosaki T (2000) Synaptic plasticity of striatal cholinergic interneurons studied in vitro. Soc Neurosci Abstr 26:683.

Thomas TM, Smith Y, Levey AI, Hersch SM (2000) Cortical inputs to M2-immunoreactive striatal interneurons in rat and monkey. Synapse 37:252-261.

Undie AS, Weinstock J, Sarau HM, Friedman E (1994) Evidence for a distinct D1-like dopamine receptor that couples to activation of phosphoinositide metabolism in brain. J Neurochem 62:2045-2048.

Washburn MS, Dingledine R (1996) Block of $\alpha$-amino-3-hydroxy-5methyl-4-isoxazolepropionic acid (AMPA) receptors by polyamines and polyamine toxins. J Pharmacol Exp Ther 278:669-678.

White NM (1997) Mnemonic functions of the basal ganglia. Curr Opin Neurobiol 7:164-169.

Wickens JR, Begg AJ, Arbuthnott GW (1996) Dopamine reverses the depression of rat corticostriatal synapses which normally follows highfrequency stimulation of cortex in vitro. Neuroscience 70:1-5.

Wilson CJ (1986) Postsynaptic potentials evoked in spiny neostriatal projection neurons by stimulation of ipsilateral and contralateral neocortex. Brain Res 367:201-213.

Wilson CJ, Chang HT, Kitai ST (1990) Firing patterns and synaptic potentials of identified giant aspiny interneurons in the rat neostriatum. J Neurosci 10:5508-5519.

Yan Z, Surmeier DJ (1996) Muscarinic (m2/m4) receptors reduce Nand $\mathrm{P}$-type $\mathrm{Ca}^{2+}$ currents in rat neostriatal cholinergic interneurons through a fast, membrane-delimited, G-protein pathway. J Neurosci 16:2592-2604.

Yan Z, Surmeier DJ (1997) $\mathrm{D}_{5}$ dopamine receptors enhance $\mathrm{Zn}^{2+}$ sensitive $\mathrm{GABA}_{\mathrm{A}}$ currents in striatal cholinergic interneurons through a PKA/PP1 cascade. Neuron 19:1115-1126.

Yan Z, Song W-J, Surmeier DJ (1997) $\mathrm{D}_{2}$ dopamine receptors reduce $\mathrm{N}$-type $\mathrm{Ca}^{2+}$ currents in rat neostriatal cholinergic interneurons through a membrane-delimited, protein-kinase-C-insensitive pathway. J Neurophysiol 77:1003-1015.

Zgombick JM, Schechter LE, Kucharewicz SA, Weinshank RL, Branchek TA (1995) Ketanserin and ritanserin discriminate between recombinant human 5-HT1D alpha and 5-HT1D beta receptor subtypes. Eur J Pharmacol 291:9-15. 